\title{
Aortic wall abnormalities in patients with aortic coarctation
}

\author{
Luis E Rodriguez Castellanos*, Gabriela Melendez, Aloha Meave, Maria Soto, Jorge I Magaña \\ From 18th Annual SCMR Scientific Sessions \\ Nice, France. 4-7 February 2015
}

\section{Background}

Aortic coarctation (AC) represents $7 \%$ of congenital heart disease. It is a reversible secondary cause of systemic hypertension, however up to $35 \%$ of patients remain hypertensive and $18 \%$ have cardiovascular complications such as aortic aneurysm, dissection or aortic valve disease. $\mathrm{AC}$ is associated with bicuspid aortic valve (BAV) in around $60 \%$, both diseases alter aortic wall distensibility, stiffness and wall shear stress (WSS). Our objective was to compare these parameters in patients with $\mathrm{AC}$ according to the morphology or the aortic valve (either bicuspid or tricuspid).

\section{Methods}

Patients with AC or significant recoarctation (maximum pressure gradient $>20 \mathrm{mmHg}$ ) who were referred for
CMR from 2013 to 2014 were included. Patients with more than mild aortic valve disease and/or contraindications to undergo CMR were excluded. Distensibility was calculated at the sinotubular junction by the formula (systolic area - diastolic area)/((diastolic area $\mathrm{x}$ (systolic pressure - diastolic pressure)). We used pulse wave velocity (PWV), a validated subrogate of stiffness, which was measured as shown in figure 1 .

\section{Results}

Thirty-nine patients with $\mathrm{AC}$ were evaluated, nine were excluded due to moderate or severe aortic valve disease and one CMR was stopped due to claustrophobia; 29 patients were analyzed (17 with BAV and 12 with tricuspid aortic valve). There was no difference in distensibility

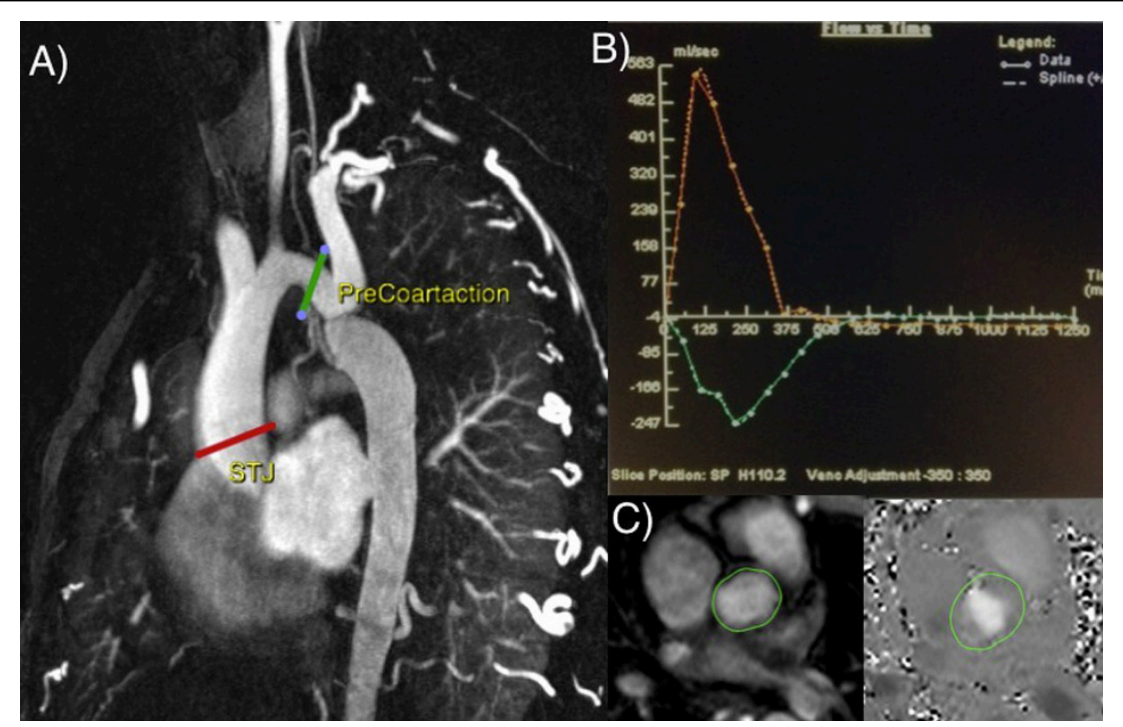

Figure 1 Magnetic resonance findings in patients with aortic coarctation and BAV.

Magnetic Resonace, National Institute of Cardiology, Mexico City, Mexico

(c) 2015 Rodriguez Castellanos et al; licensee BioMed Central Ltd. This is an Open Access article distributed under the terms of the Creative Commons Attribution License (http://creativecommons.org/licenses/by/4.0), which permits unrestricted use, distribution, and reproduction in any medium, provided the original work is properly cited. The Creative Commons Public Domain Dedication waiver (http://creativecommons.org/publicdomain/zero/1.0/) applies to the data made available in this article, unless otherwise stated. 
between patients with BAV and tricuspid aortic valve $\left[2.8 \times 10^{-3} \mathrm{mmHg}^{-}{ }^{1}\right.$ (IQR 1.3-8.1) vs $3.8 \times 10^{-3} \mathrm{mmHg}_{-}{ }^{1}$ (1.7-5.3); $\mathrm{p}=0.62$ ], PWV was not different at precoarctation aorta [1.5 m/s (IQR 1.3-3.2) vs $2.2 \mathrm{~m} / \mathrm{s}(1.1-4.6) ; \mathrm{p}=$ 0.81 ] or at postcoarctation aorta [1.4 m/s (IQR 1.1-3.9) vs $3.3 \mathrm{~m} / \mathrm{s}(1.2-10.8) ; \mathrm{p}=0.67]$. Wall shear stress was similar in both groups (4.9 dynas $/ \mathrm{cm}^{2}$ (IQR 4.1-6.0) vs 5.3 dynas/ $\mathrm{cm}^{2}$ (2.9-8.3); $\left.\mathrm{p}=0.81\right]$. Aortic diameters were not different between groups, however, we found a significant negative correlation between sinotubular junction diameter and WSS $(\mathrm{r}=-0.62 ; \mathrm{p}=0.001)$ and distensibility $(\mathrm{r}=-0.47 ; \mathrm{p}=0.02)$.

\section{Conclusions}

Aortic distensibility, stiffness, WSS and diameters were similar in bicuspid and tricuspid aortic valve patients with aortic coarctation. Distensibility and WSS negatively correlate with the aortic diameter at the sinotubular junction.

Published: 3 February 2015

doi:10.1186/1532-429X-17-S1-P204

Cite this article as: Rodriguez Castellanos et al:: Aortic wall abnormalities in patients with aortic coarctation. Journal of Cardiovascular Magnetic Resonance 2015 17(Suppl 1):P204.
Submit your next manuscript to BioMed Central and take full advantage of:

- Convenient online submission

- Thorough peer review

- No space constraints or color figure charges

- Immediate publication on acceptance

- Inclusion in PubMed, CAS, Scopus and Google Scholar

- Research which is freely available for redistribution

Submit your manuscript at www.biomedcentral.com/submit
C Biomed Central 